\title{
ASSOCIATION OF THYROID DYSFUNCTION IN WOMEN PRESENTING WITH MENSTRUAL PROBLEMS.
}

\author{
DR. NOREEN NAZAR, MBBS \\ NISHTAR HOSPITAL, MULTAN, PAKISTAN. \\ DR. MARVA MASOOD, MBBS \\ NISHTAR HOSPITAL, MULTAN, PAKISTAN. \\ DR. AYMAN FIAZ, MBBS \\ BAHAWAL VICTORIA HOSPITAL, BAHAWALPUR, PAKISTAN.
}

\begin{abstract}
;
Background; Menstrual disorders frequently affect the quality of life of adolescents and young adult women, especially those who suffer dysmenorrhoea and heavy menstruation. Different studies have associated thyroid dysfunction with menstrual problems. This study was conducted to document the frequency of hypothyroidism in women with menstrual problems. Objective; To determine frequency of thyroid dysfunction in women having menstrual problems at a tertiary care hospital. Material and methods; All the study cases (227) who meet inclusion and exclusion criteria of my study were taken from OPD of the Department of Gynecology and Obstetrics, Nishtar Hospital Multan. Once registered, $5 \mathrm{ml}$ venous blood sample was taken and sent to the central laboratory of the Nishtar Hospital Multan for serum TSH and $\mathrm{T}_{4}$ levels by a pathologist having minimum 5 years experience after post-graduation. Hypothyroidism was determined on laboratory report after serum analysis for TSH and $\mathrm{T}_{4}$. Data was analyzed by using SPSS Version 20. Results; Mean age of our study cases was noted to be $24.08 \pm 4.65$ years. Of these 227 study cases, 134 (59 \%) were married while $93(41 \%)$ were unmarried. Mean body mass index (BMI) of our study cases was $22.31 \pm 2.70 \mathrm{~kg} / \mathrm{m}^{2}, 160(70.5 \%)$ were normal weight, $51(22.5 \%)$ were overweight and $16(7 \%)$ were obese. Secondary amenorrhea was noted in $25(11 \%)$, oligomenorrhea in 42 $(18.5 \%)$, polymenorrhea in $16(7 \%)$, heavy menstrual bleeding in $59(26 \%)$ and irregular menstrual bleeding in $85(37.5 \%)$. Mean serum TSH level of our study cases was $4.85 \pm 0.91 \mathrm{mIU} / \mathrm{L}$ while mean $\mathrm{T}_{4}$ level was noted to be $86.90 \pm 38.81 \mathrm{nmol} / \mathrm{L}$ and hypothyroidism was noted in $176(77.5 \%)$ of our study cases. Overt hypothyroidism was noted in 75 (33\%) and subclinical hypothyroidism in 101 (44.5\%) of our study cases. Conclusion; Very high frequency of thyroid dysfunction was noted in women having menstrual problems in our study. Thyroid dysfunction was significantly associated with residential status, obesity, poor socioeconomic status, level of education and type of menstrual problem. Our study results suggest that women presenting with menstrual problems must be screened for thyroid hormones for proper management of these patients.
\end{abstract}

Keywords; Thyroid dysfunction, Menstrual problems, subclinical hypothyroidism, overt hypothyroidism.

DOI: $10.7176 / \mathrm{JMPB} / 67-06$

Publication date:August $31^{\text {st }} 2020$

\section{Introduction;}

Adolescence is the time of life between puberty and psychophysical maturity when crucial endocrinological, metabolic, somatic and psychological changes occur in girls. During this process, sequential phases mark the maturation of the complex endocrinological system that comprises the hypothalamus, pituitary gland, and ovary, and their interactions. Healthy reproductive function is the expected endpoint of this process ${ }^{1,2}$. The impact of 
women's menstrual cycle on her quality of life, health, work, and community is substantial. Menstrual disturbance is linked with general ill conditions such as migraine, asthma, and endocrinopathies. The clinical significance of medical interventions to prevent these conditions becomes clear if the role of genetic or environment is clarified ${ }^{3}$. Menstrual cycles act as evident indicators of underlying reproductive health ${ }^{4}$. Menstrual dysfunction reveals both infertility and increases future risk of various chronic diseases such as diabetes, breast cancer, cardiovascular diseases. Dysfunctional menstrual cycles can begin from adolescence and persist for many years and throughout reproductive life-span causing physical, psychological, and economical strains on women's life ${ }^{4,5}$.

Hypothyroidism is the most common clinical disorder of thyroid function due to decrease production of thyroid hormones. Primary hypothyroidism is invariably accompanied by increased thyrotrophin secretion. Hypothyroidism affects persons of all ages \& both sexes but more common in women ${ }^{6}$. It has been reported that thyroid dysfunction is frequently associated with menstrual disturbances, hypermenorrhea and polymenorrhea have also been reported in about $50 \sim 80 \%$ of patients with hypothyroidism. ${ }^{7}$ Hypothyroidism was present in $82 \%$ women having menstruation problems in a study conducted by Sirichand et $\mathrm{al}^{8}$. There were only 2 studies conducted in Pakistan on this topic among targeted population, one from Quetta and other from Hyderabad ${ }^{8,9}$.

\section{Material and methods}

Both married / unmarried females aged 18 - 40 years, were taken which presented with menstruation problems for more than 6 months. Women with anatomical reproductive tract abnormalities, debilitating diseases like rheumatoid arthritis, diabetes, UTI and Hypertension, pregnant women and those who were taking any medication for thyroid abnormalities were excluded from our study. All the study cases (227) who meet inclusion and exclusion criteria of my study were taken from OPD of the Department of Gynecology and Obstetrics, Nishtar Hospital Multan. Once registered, $5 \mathrm{ml}$ venous blood sample was taken and sent to the central laboratory of the Nishtar Hospital Multan for serum TSH and $\mathrm{T}_{4}$ levels by a pathologist having minimum 5 years experience after post-graduation. Hypothyroidism was determined on laboratory report after serum analysis for TSH and $\mathrm{T}_{4}$. Data was analyzed by using SPSS Version 20.

\section{Results;}

Our study included a total of 227 study cases having menstrual problems meeting inclusion criteria of our study. Mean age of our study cases was noted to be $24.08 \pm 4.65$ years (with minimum age of our study cases was 18 years while maximum age was 38 years. our study results have indicated that majority of our study cases i.e. 185 $(81.5 \%)$ were aged in range of $18-30$ years of age. Of these 227 study cases, $134(59 \%)$ were married while 93 (41\%) were unmarried. Mean height of our study cases was $159.30 \pm 8.21$ centimeters while mean weight of our study cases was noted to be $57.81 \pm 5.67$ kilograms. Mean body mass index (BMI) of our study cases was 22.31 $\pm 2.70 \mathrm{~kg} / \mathrm{m}^{2}, 160(70.5 \%)$ were normal weight, $51(22.5 \%)$ were overweight and $16(7 \%)$ were obese. Eighty five $(37.4 \%)$ belonged to rural areas while $142(62.6 \%)$ were from urban areas, $202(89 \%)$ were having poor social background and only 25 (11\%) were from middle income. Of these 227 study cases, $176(77.5 \%)$ were illiterate, $35(1.5 \%)$ were having only primary education and $16(7 \%)$ were having their education up to matriculation. Secondary amenorrhea was noted in $25(11 \%)$, oligomenorrhea in $42(18.5 \%)$, polymenorrhea in $16(7 \%)$, heavy menstrual bleeding in $59(26 \%)$ and irregular menstrual bleeding in $85(37.5 \%)$. Mean serum TSH level of our study cases was $4.85 \pm 0.91 \mathrm{mIU} / \mathrm{L}$ while mean $\mathrm{T}_{4}$ level was noted to be $86.90 \pm 38.81 \mathrm{nmol} / \mathrm{L}$ and hypothyroidism was noted in $176(77.5 \%)$ of our study cases. Overt hypothyroidism was noted in 75 (33\%) and subclinical hypothyroidism in $101(44.5 \%)$ of our study cases.

\section{Discussion;}

Menstrual disorders frequently affect the quality of life of adolescents and young adult women, especially those who suffer dysmenorrhoea and heavy menstruation ${ }^{10-12}$. The World Health Organization reports that 18 million women aged 30-55 years perceive their menstrual bleeding to be excessive ${ }^{13-14}$. Such disorders also have economic consequences in terms of health care costs due to the consumption of expensive hormonal drugs and laboratory tests. As well as health problems there can be consequences such as limitations on attendance at work and school which hinder academic achievements and employment prospects. ${ }^{15}, 16$

Our study included a total of 227 study cases having menstrual problems meeting inclusion criteria of our study. Mean age of our study cases was noted to be $24.08 \pm 4.65$ years (with minimum age of our study cases was 18 years while maximum age was 38 years. our study results have indicated that majority of our study cases i.e. 185 
$(81.5 \%)$ were aged in range of $18-30$ years of age. Karout et al ${ }^{11}$ from Lebanon also reported $20.9 \pm 1.8$ years mean which is close to our study results. Sirichand et al ${ }^{8}$ reported $28.55 \pm 5.54$ years mean age of the patients with menstrual disturbances which is similar to that of our study results. Khatiwada et al ${ }^{17}$ reported $25.7 \pm 6.8$ years mean age of the women having menstrual problems which is in compliance with that of our study results.

Of these 227 study cases, 134 (59\%) were married while 93 (41\%) were unmarried. Sirichand et al ${ }^{8}$ also reported menstrual disturbances being more prevalent in married women which is in compliance with that of our study results.

Mean height of our study cases was $159.30 \pm 8.21$ centimeters while mean weight of our study cases was noted to be $57.81 \pm 5.67$ kilograms. Mean body mass index (BMI) of our study cases was $22.31 \pm 2.70 \mathrm{~kg} / \mathrm{m}^{2}, 160(70.5 \%)$ were normal weight, $51(22.5 \%)$ were overweight and $16(7 \%)$ were obese. Rigon et al ${ }^{2}$ reported mean BMI was $21.0 \pm 2.9 \mathrm{~kg} / \mathrm{m}^{2}$ mean weight $56.5 \pm 8.9$ kilograms and mean height was $164.7 \pm 6.7$ centimeters in ladies with menstrual problems which is close to our study results

Eighty five (37.4\%) belonged to rural areas while $142(62.6 \%)$ were from urban areas, $202(89 \%)$ were having poor social background and only $25(11 \%)$ were from middle income. Sirichand et al ${ }^{8}$ reported all such patients $(100 \%)$ from poor social background which is similar to study results. Rigon et al ${ }^{2}$ reported majority of women from middle income group to high income group which is different from our results, this difference is due to high industrial growth of Italian population and this study was done in Italy.

Of these 227 study cases, $176(77.5 \%)$ were illiterate, 35 (1.5\%) were having only primary education and $16(7 \%)$ were having their education up to matriculation.

Secondary amenorrhea was noted in $25(11 \%)$, oligomenorrhea in $42(18.5 \%)$, polymenorrhea in $16(7 \%)$, heavy menstrual bleeding in $59(26 \%)$ and irregular menstrual bleeding in $85(37.5 \%)$. Karout et al ${ }^{11}$ reported secondary amenorrhea in $5.1 \%$, irregular bleeding in $53 \%$, oligomenorrhea in $10.5 \%$ and polymenorrhea $7.6 \%$. Our study results are in compliance with that of Karout et al ${ }^{11}$. Bhavani et al ${ }^{18}$ and Rigon et $\mathrm{al}^{2}$ reported similar results.

Mean serum TSH level of our study cases was $4.85 \pm 0.91 \mathrm{mIU} / \mathrm{L}$ while mean $\mathrm{T}_{4}$ level was noted to be $86.90 \pm$ $38.81 \mathrm{nmol} / \mathrm{L}$ and hypothyroidism was noted in $176(77.5 \%)$ of our study cases. Overt hypothyroidism was noted in $75(33 \%)$ and subclinical hypothyroidism in $101(44.5 \%)$ of our study cases. Hypothyroidism was present in $82 \%$ women having menstruation problems in a study conducted by Sirichand et $\mathrm{al}^{8}$ which is close to our study results. Bhavani et al ${ }^{18}$ reported subclinical hypothyroidism in $57 \%$ which is close to our study results. Ajmani et al ${ }^{19}$ and Khatiwada et al ${ }^{17}$ also reported subclinical hypothyroidism being more common in women having menstrual problems as reported in our study.

\section{Conclusion;}

Very high frequency of thyroid dysfunction was noted in women having menstrual problems in our study. Thyroid dysfunction was significantly associated with residential status, obesity, poor socioeconomic status, level of education and type of menstrual problem. Our study results suggest that women presenting with menstrual problems must be screened for thyroid hormones for proper management of these patients.

\section{References;}

1. Karapanou O, Papadimitriou A. Determinants of menarche. Reprod Biol Endocrinol. 2010 Sep 30;8:115. doi: 10.1186/1477-7827-8-115.

2. Rigon F, De Sanctis V, Bernasconi S, Bianchin L, Bona G, Bozzola M, et al. Menstrual pattern and menstrual disorders among adolescents: an update of the Italian data. Ital J Pediatr. 2012 Aug 14;38:38. doi: 10.1186/1824-7288-38-38. 
3. Jahanfar S. Genetic and environmental determinants of menstrual characteristics. Indian J Hum Genet. 2012 May;18(2):187-92. doi: 10.4103/0971-6866.100759.

4. Gumanga SK, Kwame-Aryee RA. Menstrual characteristics in some adolescent girls in Accra, Ghana. Ghana Med J. 2012;46(1):3-7.

5. Dambhare DG, Wagh SV, Dudhe JY. Age at menarche and menstrual cycle pattern among school adolescent girls in Central India. Glob J Health Sci. 2012;4(1):105-11.

6. Kalyani P. Menstrual irregularities in hypothyroidism. J Evolution Med Dent Sci. 2015;4(09):1522-7.

7. Kakuno $\mathrm{Y}^{1}$, Amino N, Kanoh M, Kawai M, Fujiwara M, Kimura M, et al. Menstrual disturbances in various thyroid diseases. Endocr J. 2010;57(12):1017-22.

8. Sirichand P, Devrajani BR, Abbasi RM, Shah SZA, Devrajani T, Bibi I. Impaired thyroid functions in patients with menstrual disturbances (An experience of a private clinic). World Applied Sci J. 2009;7(4):538-42.

9. Iqbal N, Tariq MM, Bajwa MA, Naheed R, Abbas F, Javed Y. Incidence of menstrual irregularities associated with hypothyroidism in Balochistan, Pakistan. Pak J Med Health Sci 2011;5(4):634-8.

10. Tavallaee $\mathrm{M}^{1}$, Joffres MR, Corber SJ, Bayanzadeh M, Rad MM. The prevalence of menstrual pain and associated risk factors among Iranian women. J Obstet Gynaecol Res. 2011 May;37(5):442-51.

11. Karout $\mathrm{N}^{1}$, Hawai SM, Altuwaijri S. Prevalence and pattern of menstrual disorders among Lebanese nursing students. East Mediterr Health J. 2012 Apr;18(4):346-52.

12. Lambert-Messerlian G, Roberts MB, Urlacher SS, Ah-ching J, Viali S, Urbanek M, et al. First assessment of menstrual cycle function and reproductive endocrine status in Samoan women. Hum Reprod., 2011;26:2518-24.

13. Glueck $\mathrm{CJ}^{1}$, Morrison JA, Daniels S, Wang P, Stroop D. Sex hormone-binding globulin, oligomenorrhea, polycystic ovary syndrome, and childhood insulin at age 14 years predict metabolic syndrome and class III obesity at age 24 years. J Pediatr. 2011 Aug;159(2):308-13.

14. Ibáñez L ${ }^{1}$, López-Bermejo A, Díaz M, Marcos MV, de Zegher F. Early metformin therapy (age 8-12 years) in girls with precocious pubarche to reduce hirsutism, androgen excess, and oligomenorrhea in adolescence. J Clin Endocrinol Metab. 2011 Aug;96(8):E1262-7.

15. Dekelbab $\mathrm{BH}^{1}$, Abou Ouf HA, Jain I. Prevalence of elevated thyroid-stimulating hormone levels in obese children and adolescents. Endocr Pract. 2010 Mar-Apr;16(2):187-90.

16. Velayutham $\mathrm{K}^{1}$, Selvan $\mathrm{SS}^{1}$, Unnikrishnan $\mathrm{AG}^{2}$. Prevalence of thyroid dysfunction among young females in a South Indian population. Indian J Endocrinol Metab. 2015 Nov-Dec;19(6):781-4.

17. Khatiwada S, Gautam S, KC R, Singh S, Shrestha S, Jha P, et al. Pattern of Thyroid Dysfunction in Women with Menstrual Disorders. Ann Clin Chem Lab Med. 2016:2(1);3-6

18. Bhavani N, Sathineedi A, Giri A, Chippa S, Reddy VSP. A study of correlation between abnormal uterine bleeding and thyroid dysfunction. J Recent Trends Sci Technol. 2015;14(1):131-35.

19. Ajmani NS ${ }^{1}$, Sarbhai $\mathrm{V}^{1}$, Yadav $\mathrm{N}^{1}$, Paul M${ }^{1}$, Ahmad A ${ }^{1}$, Ajmani $\mathrm{AK}^{2}$. Role of Thyroid Dysfunction in Patients with Menstrual Disorders in Tertiary Care Center of Walled City of Delhi. J Obstet Gynaecol India. 2016 Apr;66(2):115-9. 